\title{
"Corporate social environmental reporting and stock prices: an analysis of listed firms in Nigeria"
}

\author{
Omoike Osereme Amiolemen iD https://orcid.org/0000-0002-3490-9138 \\ R http://www.researcherid.com/rid/G-2977-2018 \\ Uwalomwa Uwuigbe iD https://orcid.org/0000-0001-8769-3492 \\ R http://www.researcherid.com/rid/G-2903-2018 \\ AUTHORS \\ Olubukola Ranti Uwuigbe iD https://orcid.org/0000-0002-6566-1083 \\ R http://www.researcherid.com/rid/G-2929-2018 \\ Ilogho Simon Osiregbemhe iD https://orcid.org/0000-0001-5890-5070 \\ R http://www.researcherid.com/rid/G-2844-2018 \\ Ajetunmobi Opeyemi iD https://orcid.org/0000-0003-0127-2879 \\ R http://www.researcherid.com/rid/G-2908-2018
}

Omoike Osereme Amiolemen, Uwalomwa Uwuigbe, Olubukola Ranti Uwuigbe, ARTICLE INFO llogho Simon Osiregbemhe and Ajetunmobi Opeyemi (2018). Corporate social environmental reporting and stock prices: an analysis of listed firms in Nigeria. Investment Management and Financial Innovations, 15(3), 318-328. doi: 10.21511/imfi.15(3).2018.26

DOI http://dx.doi.org/10.21511/imfi.15(3).2018.26

RELEASED ON

Friday, 21 September 2018

RECEIVED ON

Monday, 12 March 2018

ACCEPTED ON

Friday, 17 August 2018

(c) EY

LICENSE

This work is licensed under a Creative Commons Attribution 4.0 International License

JOURNAL Investment Management and Financial Innovations"

ISSN PRINT $1810-4967$

ISSN ONLINE $1812-9358$

PUBLISHER

LLC "Consulting Publishing Company "Business Perspectives"

FOUNDER

LLC "Consulting Publishing Company "Business Perspectives"

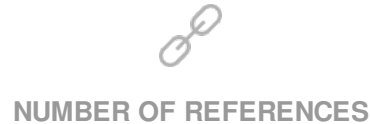

73
NUMBER OF FIGURES

0
ニニ:-

NUMBER OF TABLES

5

(C) The author(s) 2022. This publication is an open access article. 


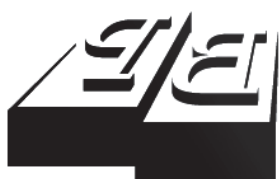

BUSINESS PERSPECTIVES

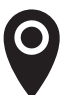

LLC “CPC "Business Perspectives" Hryhorii Skovoroda lane, 10, Sumy, 40022, Ukraine

www.businessperspectives.org

Received on: $12^{\text {th }}$ of March, 2018 Accepted on: $17^{\text {th }}$ of August, 2018

(c) Omoike Osereme Amiolemen, Uwalomwa Uwuigbe, Olubukola Ranti Uwuigbe, Ilogho Simon Osiregbemhe, Ajetunmobi Opeyemi, 2018

Omoike Osereme Amiolemen, Ph.D. Student, Department of Accounting, Covenant University, Ota, Ogun State, Nigeria.

Uwalomwa Uwuigbe, Professor, Department of Accounting, Covenant University, Ota, Ogun State, Nigeria.

Olubukola Ranti Uwuigbe, Professor, Department of Accounting, Covenant University, Ota, Ogun, Nigeria.

Ilogho Simon Osiregbemhe, Ph.D. Student, Department of Accounting, Covenant University, Ota, Ogun State, Nigeria.

Ajetunmobi Opeyemi, Ph.D. Student, Department of Accounting, Covenant University, Ota, Ogun State, Nigeria.

\section{(c) (i)}

This is an Open Access article, distributed under the terms of the Creative Commons Attribution 4.0 International license, which permits unrestricted re-use, distribution, and reproduction in any medium, provided the original work is properly cited.
Omoike Osereme Amiolemen (Nigeria), Uwalomwa Uwuigbe (Nigeria), Olubukola Ranti Uwuigbe (Nigeria), Ilogho Simon Osiregbemhe (Nigeria), Ajetunmobi Opeyemi (Nigeria)

\section{CORPORATE SOCIAL} ENVIRONMENTAL REPORTING AND STOCK PRICES: AN ANALYSIS
OF LISTED FIRMS IN NIGERIA

\begin{abstract}
The study investigated Corporate Social Environmental Reporting and its association with stock prices (using market price per share as at the financial year end) among listed firms in Nigeria. The study used a cross-sectional research design comprising 50 publicly listed companies across various sectors for the period of five years (20112015). For the selected firms, the annual report was used to collect the data. This research utilizes the panel data regression in analyzing the influence of the independent variable (measured by corporate social and environmental expenditure) on the dependent variable measured using the market price per share) for the respective years. Also, in an attempt to examine the relatively market price per share across the sampled industries, the study made use of the one-way analysis of variance; while the Granger causality test was also conducted to ascertain whether bi-directional relationships exist between explanatory variable and the dependent variable (i.e. corporate social and environmental expenditure and market price per share). Findings from the study revealed that the association between corporate social and environmental expenditure and the market price of the firm (when considered in aggregate) is not significant. The result from the Analysis of Variance (ANOVA) showed that the market price per share is significantly different across the industries.
\end{abstract}

\section{Keywords}

environmental disclosure, social environmental expenditure, stock prices, market price per share

\section{JEL Classification $\quad$ M14, M41, M42}

\section{INTRODUCTION}

Climate change and its impact on the activities of mankind on the environment has increased over the years with amplified public interest and scrutiny on the operations of corporations. These have necessitated the cries from stakeholders for firms to disclose corporate environmental information in their statement of financial position annually. Corporate environmental disclosure as the term implies can be described as the various ways in which companies disclose by announcing information on actions and the effects on the environmental or operations on the environment to the users of financial statement (Alok, Nikhil, \& Bhagaban, 2008). Thus, environmental disclosure is paramount not only to report on the economic and monetary activities of companies, but also to reflect the environmental impact of the firm's activities on the environment and the amount being spent to clean up the environment. Over the years, firms involved in the disclosure of their environmental information based on their sustainability policies have increased, specifically since the first independent corporate environmental and sustainable reports were published in 1989 (Uwuigbe et al., 2017). Thus, corporate social, environmental sustain- 
ability reporting has not only become more important, but also serves as a competitive advantage for firms involved in sustainability reporting. The concept is likewise understood as the obligatory contribution of organizations and businesses towards sustaining increased productivity, and growth of the economy, work with employees, their families, local stakeholders in general to increase the tone of aliveness (the World Business Council for Sustainable Development, 2002).

It is important to note that the capital markets across the globe basically respond to information about organizations financial and environmental performance. It may respond negatively to news of adverse environmental impact (such as oil spills, or violations of permits) and it may also respond positively to information relating to organizations environmental clean-up (Dasgupta \& Mamingi, 1998). The scrutiny of the relationship between financial performance and corporate environmental performance have been carried out by many studies. However, the outcome from such these studies has been inconsistent based on the choice of proxies and control variables used and the existing environmental policies that exist in such countries (Priyanka, 2013; Balabanis, Phillips, \& Lyall, 1998; Tsoutsoura, 2004; Uwuigbe et al., 2017). More so, there has been series of documented studies relating to Corporate Social Responsibility (CSR) and corporate financial performance both in developed and developing economies (Balabanis, Phillips, \& Lyall, 1998; Tsoutsoura, 2004; Uwuigbe \& Olusanmi, 2012; Olayinka \& Temitope, 2011; Uwuigbe et al., 2016; Ajide \& Aderemi, 2014; Okegbe \& Egbunike, 2016; Olubukola, et al., 2016), as well as emerging economies (Aras, Aybars, \& Kutlu, 2009; Crisostomo, Freire, \& De Vascincellos, 2011). Despite these avalanches of prior studies that exist in the literature, none of these studies especially in Nigeria has attempted to examine the impact corporate social and environmental disclosure on stock market prices in Nigeria. Hence, the study examined the relationship between corporate social and environmental expenditure and market price of firms. In addition, it also attempted to find out whether a bi-directional relationship exists between corporate social and environmental expenditure and stock market price.

As a follow up to the introductory section, this paper can be previewed as follows: the first section is focused on the review of previous and existing studies that have a relationship with this study, as well as the development of the hypotheses. The second section of this paper covers the adopted research method to be used for this study. Finally, the third and final section gives insight into the results, conclusion and what this study recommends as related to the results found.

\section{LITERATURE REVIEW AND HYPOTHESES DEVELOPMENT}

Over many years, there have been a lot of environmental incidents that have affected the environment negatively and this has led to the loss of means of livelihood of occupants in such region or nations. Some of the environmental catastrophes that have negatively affected the ecosystem comprise the Dust Bowl in Canada and the United States between 1934 and 1939, the Niger Delta oil spill, where over 2.4 million barrels of crude where spilled in 4,835 incidents between 1976 and 1996. These extensive environmental phenomenon in the 70 's and 80 's led to the establishment of a lot of organizations including the Brundtland Commission's report in 1987 (titled Our Common Future) that narrate sustainable development as the expansion, which attends to the necessity of present generation without undermining the power of succeeding generations to meet their own needs.

In Africa, the introduction and application of corporate social and environmental reporting is at the elementary stage, as companies especially in Nigeria and South Africa are taking more proactive steps towards the promotion of a sustainable environment. However, the production sector in Nigeria to some extent have been involved in optional declaration of social and environmental information (Owolabi, 2010; Uwuigbe et al., 2016; Uwuigbe, 2012; Ozordi et al., 2018). This concept according to Dahlsrud (2008) has remained uncertain in corporate and academic world, as most 
of the definitions provided have been influenced towards principal interest, which hinders the development and actualization of the concept.

\subsection{Related theories}

A three-dimensional conceptual model of social responsibility, as developed by Caroll (1978), is inclusive of the categories in legal, discretionary, and economic responsibilities. The second deals with the social issues as consumerism, environmental, as well as occupational safety, as well as similar issues of social environmental reporting. The third deals with social responsiveness strategies (Caroll, 1978). It basically involves the obligation by the engagement of stakeholder to improve the social, economic, as well as the environmental situation in the communities. Several factors are usually responsible for the changes in the price of shares, especially in a competitive stock market.

\subsection{Stakeholder theory}

The theory believes that managers of organizations have a responsibility to contemplate and balance the interests of all interest groups (Freeman, 1984). Under this theory, firms are assumed to be accountable towards a broad range of stakeholders (future generations, suppliers, government, customers, community, employees, environment, etc.) (Freeman, 1984). The theory basically dissuades attention from constructing business success to focusing on who share its successes. Thus, the relationship between firms and society can be improved through corporate social and environmental reporting. Furthermore, the theory believes that stakeholders should not be undermined, since they can invoke actions that can threaten or bring about firms' failure as a result of their inability to perform the duty of care (Freeman, 2004). Therefore, organizations must strive to ensure that stakeholders are treated right.

\subsection{Legitimacy theory}

This theory basically debates about the consensus between companies and society. The theory talks about the situation whereby organizations embraces a socially-oriented behavior in order to gain access to a social endorsement or acceptance of the environment in which they are domiciled (Guthrie
\& Parker, 1989). The theory is of the opinion that corporate bodies to carry out actions not only targeted at maximizing profit, but also intensifying the shareholders wealth and carrying out activities in such a way as not to garble the host communities (Anbumozhi, Chotichanathawewong, \& Murugesh, 2011). Under this theory, the survival of the social engagement between host communities and firms is important for the effective legitimation development (Mathews, 1993). Here, while the host community's offers firms with the required materials for production, organizations manufacture goods and services and produce waste that alters the activities of the host communities where they operate. However, the association under this theory could be endangered by the disruption of unequivocal and inherent terms of the engagements. The existence of corporations can be jeopardized if a loss of the legitimacy process arises. This theory has been widely used in providing explanations to the existence of Corporate Social \& Environmental Reporting (O’Donovan, 2002). Presently, shareholders are no longer pleased with organizations just providing goods and services and making profits, but currently demands businesses to incur cost if they must in other to reduce or prevent environmental degradation, to ensure that the consumers' interest, safety of employees and safeguard the interest of host communities where the products are manufactured (Deegan \& Rankin, 1997; Uwuigbe, 2012).

One of the main discrepancies between the two schools of thought is that legitimacy theory centers on society as a whole, while the stakeholder theory debates on the specific groups in society (Deegan, 2009). In addition, it fails to give an answer to the question of worth rather that it emphasizes the outcome with the assumption that an enterprise produces value and the claim of stakeholders on this value is as a result of the notion that society creates enterprise. More so, it does not provide an auxiliary solution to the question of who, or what, generates pecuniary worth, but stresses on the flow of the outcome assuming value is produced by the enterprise itself and that stakeholders have a claim on the value, because the enterprise is a creature of society. More so, the stakeholder theory generates a space for enquiries on what sort of theory would determine whose interest is stronger, and to which interests manag- 
ers should respond where stakes conflict. Nothing this pitfall, this study adopts the legitimacy theory as the lens that explains and predicts the relation between corporate social and environmental reporting and stock market behavior. In summary, the theory suggests that corporations should not only be profit minded when doing business, but also they must ensure that all activities carried out by them should not affect the community negatively (Anbumozhi, Chotichanathawewong, \& Murugesh, 2011). In this scenario, the survival of the social agreement between the concerned parties (companies and the societies) is salient to the successful legitimation process (Mathews, 1993). This theory has been widely used in providing explanations for the existence of Corporate Social \& Environmental Reporting (O’Donovan, 2002).

\subsection{Review of prior literature}

The level of awareness of corporate social environmental responsibilities in developing countries appears to be growing (Che Zuriana, Kasumalinda, \& Rapiah, 2002; Abdul-Hamid, 2004). The manufacturing sector in Nigeria comprises firms mostly involved in environmental reporting System (Uwuigbe, 2011; Uwuigbe, 2012). However over the years the Nigerian banking sector has been on the spot light or received attention from stock exchange regulators and CBN with regard to sustainability issues. Hence, the transition to sustainability has led to or influenced profitability and shareholders fund (Uwuigbe et al., 2016). According to Pamela and Robin (1998), there have been numerous research works in the last 25 years on the effect of corporate social environmental actions.

Over the years, evidence from prior studies shows that the impact of corporate social environmental activities on firm's financial performance has been examined in recent times. The extent of concern shown by organizations to corporate social environmental activities and the pressure from stakeholders differs depending on the sector (Zhang, 2016). The unending debate on corporate social environmental disclosures has been ongoing for decades with the increasing demand for corporate accountability (Waddock, 2004).

Jaggi and Freedman (1992), in a related study on the impact of pollution performance on economic and market performance in pulp and paper firms, observed that firms were interested in the environmentally centered performance of the organization due to the long-run positive financial implication, which is beneficial. Dowell et al. (2000) found a positive relationship between market value and environmental standard. Kumar et al. (2002) in their study established a positive relationship between social behavior and the stock market.

In summary, evidence from prior studies show that while some literature discovers a positively significant relationship between corporate social environmental reporting and corporate financial performance (King \& Lenox, 2001; Nakao et al., 2007; Guenster, Bauer, Derwall, \& Koedijk, 2011; Yungchich, 2011; Oba, Fodio, \& Soje, 2012; Griffin \& Sun, 2012; Akinlo \& Iredele, 2014; Nnamani, Onyekwelu, \& Ugwu, 2017), others observed that no statistically significant relationship exist between the variables (Mcwilliams \& Siegel, 2001; Fauzi, 2009; Fiori, Di Donato, \& Izzo, 2009). The lack of consensus on the nature of the relationship between the variables has been attributed by the studies to methodological problems, omission of control variables, measurement problems and lack of causality. Furthermore, Allouche and Laroche (2005) highlighted data differences as a reason for the varied empirical results. Other studies are of the opinion that there is no statistical significance between environmental and financial performance (Kenneth et al., 1985; Alan, Donald, David, \& Rob, 2005; Mahoney \& Robert, 2007; Moneva \& Ortas, 2008; Jacobs, Singhal, \& Subramanian, 2010; Buys, Oberholzer, \& Andrikopoulous, 2011; Venanzi, 2012; Solabomi \& Uwuigbe, 2013; Solomon, Oyerogba, \& Olaleye, 2014; Sukanya, Rebekah, \& Yudhvir, 2015). These studies as described above observed that there is no consensus as to the nature of the relationship between corporate social environmental reporting and financial performance. Hence, this study examined the relationship between corporate social and environmental expenditure and the market price of firms in Nigeria.

\subsection{Development of hypotheses}

From the literature reviewed, the hypotheses have been postulated in their null form. 
$H_{01}: \quad$ Corporate social and environmental expenditure has no effect on the market price per share of firms.

$H_{02}$ : There is no significant difference using the market price per share in the stock price of firms across the industries.

$H_{03}:$ There is no bi-directional relationship between corporate social and environmental expenditure and market price per share in the various industries.

\section{METHODOLOGY}

The engagement of financial and non-financial firms in corporate social environmental expenditure in the country constituted the basis from which the sample size was selected. The selection was based on the availability of the data, as several annual reports were not available at the Nigerian Stock Exchange library or the company's websites. A total of 50 publicly listed companies were selected and the study focused on the period from 2011 to 2015. The study used the panel regression analysis and the Granger causality test to analyze the association between corporate social and environmental expenditure and the stock prices. Jacobs, Leamer, and Ward (1979) opined that they are sensitive to misspecification, however, this study used both tests in its analysis. Stock prices were used as a proxy for the performance of the stocks as against stock return considering the fact that the payment of dividend is a matter of company policy. A number of highly profitable firms might decide to retain profits for expansion rather than paying out to shareholders. Stock prices would provide better insight into the performance of the stocks, irrespective of whether dividend is paid or not (Summers, 1986).

\subsection{Model specification}

The model is structured based on panel regression analysis in the following functional form:

$$
S P_{i t}=f\left(C S E E_{i t}, F S I Z E_{i t}, \text { PROF }_{i t}\right) .
$$

The equation is explicitly stated for the hypotheses as:
$S P_{i t}=\beta_{0}+\beta_{1} C S E E_{i t}+$

$+\beta_{2}$ FSIZE $_{i t}+\beta_{3} P R O F_{i t}+\varepsilon_{i t}$,

where $S P$ - stock price, CSEE - corporate social and environmental expenditure, FSIZE firm size, $P R O F$ - profitability.

\subsection{Variables measurements}

The measurements of the independent variables are shown in Table 1.

Table 1. Construct of the control variables

\begin{tabular}{|c|c|c|}
\hline $\begin{array}{c}\text { Explanatory } \\
\text { variables }\end{array}$ & Measurement & Sources \\
\hline Stock prices & $\begin{array}{l}\text { Market price per } \\
\text { share }\end{array}$ & Ohlson (1995) \\
\hline $\begin{array}{l}\text { Corporate Social } \\
\text { Environmental } \\
\text { Expenditure } \\
\text { (CSEE) }\end{array}$ & $\begin{array}{l}\text { Total donations on } \\
\text { corporate social } \\
\text { environmental } \\
\text { activities }\end{array}$ & $\begin{array}{l}\text { Abdulrahman (2013), } \\
\text { Solomon, Oyerogba, } \\
\text { and Olaleye (2014) }\end{array}$ \\
\hline $\begin{array}{l}\text { Profitability } \\
\text { (PROF) }\end{array}$ & Earnings per share & $\begin{array}{l}\text { Barako, Hancock, } \\
\text { and Izan }(2006)\end{array}$ \\
\hline Firm size (FSIZE) & $\begin{array}{l}\text { natural log of total } \\
\text { assets }\end{array}$ & $\begin{array}{l}\text { Wan Hussin, Che- } \\
\text { Adam, Lode, and } \\
\text { Kamardin (2005) }\end{array}$ \\
\hline
\end{tabular}

Table 2. Variable definition for this study

\begin{tabular}{|c|c|}
\hline MPS & Market price per share \\
\hline CSEE & $\begin{array}{l}\text { Corporate social and environmental } \\
\text { expenditure }\end{array}$ \\
\hline FSIZE & Firm size \\
\hline PROF & Profitability \\
\hline
\end{tabular}

\subsection{Data analysis and discussion of findings}

\subsubsection{Results (descriptive analysis)}

Table 3 depicts the descriptive statistics result for the dependent variable (market price per share) and the independent variables (corporate social and environmental expenditure, firm size and earnings per share). It can be seen from the table that amongst the sampled companies, the mean MPS is N0.45 out of a minimum of N0.50 and a maximum of N120, which shows a relatively poor market price for a greater number of the companies. The minimum CSEE is 0 and the maximum is $\mathrm{N} 1,500,000,000$, with an average of N73,700,000. This shows the extent to which the sampled firms are committed to their corporate social and environmental responsibilities. For the control variables, the sampled firms have an av- 
erage total asset of $\mathrm{N} 19,300,000,000$, which shows that the firms are relatively large and the average EPS of N2.09 shows that the firms are profitable.

Table 3. Descriptive statistics

\begin{tabular}{l|c:c:c:c:c}
\hline \multicolumn{1}{c|}{ Variable } & OBS & MIN & MAX & MEAN & $\begin{array}{c}\text { STD. } \\
\text { DEV }\end{array}$ \\
\hline$S P$ & 247 & 0.50 & 1200 & 45.20 & 132.24 \\
CSEE & 247 & 0.00 & $1.5 \mathrm{E} 9$ & $7.37 \mathrm{E} 7$ & $2.04 \mathrm{E} 8$ \\
FSIZE & 247 & $5.30 \mathrm{E} 8$ & $3.75 \mathrm{E} 12$ & $1.93 \mathrm{E} 11$ & $5.72 \mathrm{E} 11$ \\
PROF & 247 & -2002 & 2955 & 209 & 473.13 \\
\hline
\end{tabular}

Note: For variable description $\mathrm{E}$ represents the number of zeros.

\subsubsection{Correlation analysis}

It is important to check for multicollinearity before proceeding with the regression analysis. Table 4 presents the correlation results for the dependent and independent variables. There is no presence of multicollinearity apart from the pairs board size and firm size $(r=0.63)$, and board shareholding and CEO incentive $(r=0.52)$ no other relationship exceeds the $50 \%$ mark.

Table 4. Correlation matrix

\begin{tabular}{c:c:c:c:c}
\hline Variables & $\boldsymbol{S P}$ & $\boldsymbol{C S E E}$ & $\boldsymbol{F S I Z E}$ & $\boldsymbol{P R O F}$ \\
\hline $\boldsymbol{S P}$ & 1.00 & - & - & - \\
\hdashline $\boldsymbol{C S E E}$ & 0.05 & 1.00 & - & - \\
\hdashline $\boldsymbol{F S I Z E}$ & 0.30 & $0.29^{* * *}$ & 1.00 & - \\
\hdashline $\boldsymbol{P R O F}$ & $0.12^{*}$ & $0.17^{* * *}$ & $0.28^{* * *}$ & 1.00 \\
\hline
\end{tabular}

Notes: $S P$ - stock price, CSEE - corporate social and environmental expenditure, FSIZE - firm size, PROF profitability ${ }^{*}{ }^{* *},{ }^{* *}$ indicate significance at $10 \%, 5 \%$, and $1 \%$, respectively.

\subsubsection{Panel data regressions}

To estimate the model, the dependent variable fluctuation in stock prices is measured using the market price per share (kobo) for the respective years. The result of the Ramsey RESET test with and $F$-statistic value of $(F=1.12, P=0.34)$. The test shows that there are no omitted variables in the model and as such the model is correctly specified. Based on the outcome as provided by the Breuch Pagan Langrangian Multiplier test, the null hypothesis is rejected, as it is revealed in the result. This is evident in the Chisquare values of $\chi^{2}=147.51$ and $p$-value $=0.00$, respectively. Thus, the variance result from the random effect reveals that it is not equal to zero, hence, according to the rule of thumb, the random effect model is the most suitable for this research. However, comparing the result from the random effects model and the fixed effect model, the results implies that the coefficients of the fixed effect model and the random effect model have no significant difference. This is apparent in the Hausman test with Chi-square value $\chi^{2}=1.67$ and a $p$-value $=0.64$, respectively. Thus, the random effect is preferred. The heteroscedasticity test further shows that shows that the model is both heteroskedastic and autocorrelated (see appendices). This is also evident in the probability values of $P<0.00$. Findings from the random effects modm el as depicted in Table 5 presents a $R^{2}=0.09$. This implies that the explanatory variables account for only $9 \%$ of the changes in the dependent variable. This means that there are other factors outside the variables considered for this study are responsible for the changes in the dependent variable. Findings relating to the robust random effects regression model show that an insignificant relationship exists between corporate social environmental disclosure (CSEE) and stock price in Nigeria. This is evident in the probability value of $(p>0.10 ; \beta=0.43$,). Conversely, findings as it relates to the second postulation for this study indicate that there is a significant positive difference between stock price of firms and firms across the industries. This is also evident in the values provided in Table 5 where market price per share is $(\beta=3.32, p<.01)$. In addition, the study observed that there was no significant difference between profitability and corporate social environmental disclosure (see Table $5 \beta_{1}=0.57, p>.10$ ). Furthermore, the Granger causality tests were conducted to test if a bi-directional relationship exists between CSEE and MPS. The results from Table 7 show that CSEE does not Granger cause MPS and likewise, MPS does not Granger cause CSEE, which also is in tandem with the results obtained from the panel regression analysis.

\subsubsection{Analysis of variance}

Furthermore, in another test of the second hypothesis of the study that states that all industries in Nigeria have equal market prices, the market price per share is compared across industries using the one-way analysis of variance (see Table 5). From Table 5, the F-statistic with a value of 3.151 and probability value of 0.001 show that the stock prices as captured by the market price per share of firms in Nigeria are significantly different. 
Table 5. One-way analysis of variance for comparison of stock prices within industry

\begin{tabular}{l|c|c|c|c|c}
\hline \multicolumn{1}{c|}{ Source } & SS & DF & MS & F & Prob > F \\
\hline Corrected model & 5066.029 & 10 & 50668.303 & 3.151 & 0.001 \\
Intercept & 183276.145 & 1 & 183276.145 & 11.397 & 0.001 \\
Industry & 506683.029 & 10 & 50668.303 & 3.151 & 0.001 \\
Error & 3795127.985 & 236 & 16081.051 & - & - \\
Total & 4806426.526 & 247 & - & - & - \\
Corrected total & 4301811.014 & 246 & - & - & - \\
\hline
\end{tabular}

\section{CONCLUSION AND RECOMMENDATIONS}

The study examined the relationship between corporate social and environmental expenditure and stock prices of firms in Nigeria. The study analyzed fifty (50) selected publicly quoted companies for the period 2011-2015 (based on the availability of annual reports). The study observed that corporate social environmental expenditure have no significant effect on the market prices of firms. The study also observed that the market price of firms (financial performance) does not affect corporate social and environmental expenditure. Hence, the investment decisions of shareholders in publicly quoted firms in Nigeria are not significantly influenced by the environmental and social activities of these companies. Interestingly, this outcome is consistent with the works of Venanzi (2012), Solomon, Oyerogba, and Olaleye (2014), Sukanya, Rebekah, and Yudhvir (2015). The insignificant results could be attributed to the low level of awareness of the importance of corporate social responsibility by most investors in the Nigerian market. They do not place high value on companies taking out of their resources to give back to the society, rather they would be more attracted to companies making high profit and probably paying a relatively high dividend Consistent with the propositions of the stakeholder theory, there is a need for more awareness and education on the subject of corporate social and environmental performance of the firms as this could change the perspectives of investors to place high value on firms that consider the needs of all stakeholders most especially the society and environment where they operate rather than focussing on the shareholder group that are more inclined towards the profit motive of the firm. There is also the need for tougher regulations and sanctions by the government through regulatory bodies for organizations with poor environmental management practices.

\section{LIMITATIONS/FUTURE RESEARCH}

This study encountered limitations of which could serve as launching pads for future research works. Future studies could examine the relationship between disaggregated environmental practices and environmentally related competitiveness. This is against the backdrop of conflicting and contradicting findings (Priyanka, 2013). In addition, future research in this area could consider more years.

\section{ACKNOWLEDGMENT}

We acknowledge Covenant University for the platform and financial support provided toward the completion and publication of this research work.

\section{REFERENCES}

1. Abdulrahman, S. (2013). The influence of corporate social responsibility on profit after tax of some selected deposit money banks in Nigeria. Educational Research, 4(10), 722-732. http:/ dx.doi.org/10.14303/er.2013.213
2. Alan, M., Donald, S., David, P., \& Rob, G. (2005). Do Financial Markets Care About Social and Environmental Disclosure? Further Evidence and Exploration from the UK. Center for Social and Environmental Accounting
Research. Retrieved from https:// www.st-andrews.ac.uk/media/ csear/.../CSEAR

3. Alok, K. P., Nikhil, C. S., \& Bhagaban, D. (2008). Corporate Environmental Reporting: An Emerging Issue in the Corporate 
World. International Journal of Business and Management, 3(12), 146-156. Retrieved from scholar. google.com/citations? user $=4$ IZOC PQAAAAJ\&hl=en

4. Akinlo, O. O., \& Iredele, O. O. (2014). Corporate Environmental Disclosure and Market Value of Quoted Companies in Nigeria. The Business \& Management Review, 5(3), 171-184. Retrieved from http://www.abrmr.com/myfile/ conference_proceedings/Con Pro_78450/v5n3itrac14-31.pdf

5. Alan, M., Donald, S., David, P., \& Rob, G. (2005). Do Financial markets Care about Social and Environmental Disclosure? Further Evidence and Exploration from the UK. Centre for Social \& Environmental Accounting Research. Retrieved from https:// www.st-andrews.ac.uk/media/ csear/discussion-papers/CSEAR_ dps-finance-dofinmar.pdf

6. Anbumozhi, V., Chotichanathawewong, Q., \& Murugesh, T. (2011). Information Disclosure Strategies for green industries (No work paper /2011/08/22/4678). Bangalore. Retrieved from https://www.adb. org/sites/default/files/publication/156160/adbi-wp305.pdf

7. Aras, G., Aybars, A., \& Kutlu, O. (2009). Managing Corporate Performance: Investigating the Relationship between Corporate Social Responsibility and Financial Performance in Emerging Markets. International Journal of Productivity \& Performance Management, 59(3), 229-254. https://doi. org/10.1108/17410401011023573

8. Balabanis, G., Phillips, H. C., \& Lyall, J. (1998). Corporate Social Responsibility and Economic Performance in the top British Firms: Are they linked? European Business Review, 98(1), 25-44.

9. Barako, D., Hancock, P., \& Izan, H. (2006). Factors influencing voluntary corporate disclosure by Kenyan companies. Corporate Governance: An International Review, 14(2), 107-125. https:// doi.org/10.1111/j.14678683.2006.00491.x
10. Bartlett, A. A. (2012). The Meaning of Sustainability. Teachers Clearinghouse for Science and Society Education Newsletter, 31(1), 1-17 Retrieved from www.albartlett.org/ articles/art_meaning_of sustainability_2012mar20.pdf

11. Backstrom, S., \& Karlsson, J. (2015). Corporate Sustainability and Financial Performance - The influence of board diversity in a Swedish context (Master's Thesis). Retrieved from https:// www.diva-portal.org/smash/get/ diva2:822784/FULLTEXT01.pdf

12. Barnett, M., \& Salomon, R. M. (2012). Does it pay to be really good? Addressing the Shape of the relationship between Social and Financial Performance. Strategic Management Journal, 33(11), 1304-1320. https://doi. org/10.1002/smj.1980

13. Buys, P., Oberholzer, M., \& Andrikopoulous, P. (2011). An Investigation of the Economic Performance of Sustainability Reporting Companies versus non-reporting Companies: A South African Perspective. Journal of Social Sciences, 29(2), 151158. Retrieved from http://www. krepublishers.com/02-Journals/ JSS/JSS-29-0-000-11-Web/JSS-292-000-11-Abst-Pdf/JSS-29-2-15111-1192-Buys-P/JSS-29-2-151-111192-Buys-P-Tt.pdf

14. Caroline, F. (2012). Corporate Social Responsibility and Stock Prices: The Environmental Awareness of Shareholders. MIT Sloan School of Management. Retrieved from https://corporatesustainability.org/wp-content/uploads/arcs-2012-Flammer.pdf

15. Caroll, A. B. (1979). A ThreeDimensional Conceptual Model of Corporate Performance. Academy of Management, 4(4). https://doi. org/10.2307/257850

16. Che Zuriana, M. J., Kasumalinda, A., \& Rapiah, M. (2002). Corporate Social Responsibility Disclosure in the annual reports of Malaysian Companies: A longitudinal Study. Social and Environmental Accounting Journal, 22(2), 5-9. https:// doi.org/10.1080/096916 0X.2002.9651677

17. Chen, C. R. Y., \& Lee, C. (2015). Quantile Causality between Corporate Social Responsibility and Corporate Performance. Proceedings of the Second Asia - Pacific Conference on Business, Economics, Finance and Social Sciences. Retrieved from http:// globalbizresearch.org/Vietnam Conference/pdf/V570.pdf

18. Crisostomo,V. L., Freire,F. S., \& De Vascincellos, F. C.

(2011). Corporate Social Responsibility, Firm Value and Financial Performance in Brazil. Social Responsibility Journal, 7(2), 295-309. https://doi. org/10.1108/17471111111141549

19. Dahlsrud, A. (2008). How Corporate Social Responsibility is defined: An Analysis of 37 Definitions. Wiley InterScience, 15, 1-13. Retrieved from https:// onlinelibrary.wiley.com/doi/ pdf/10.1002/csr.132

20. Dasgupta, S., \& Mamingi, N. (1998). Capital Market Responses to Environmental Performance in Developing Countries (World Bank Policy Research working paper, 1-42). Retrieved from web.worldbank.org/archive/website01004/ WEB/IMAGES/12852832.PDF

21. Davidson, Wallace, N., \& Dan, L.W. (1990). A Comparative Test of the Use of Accounting and Stock Market Data Relating Corporate Social responsibility and financial performance. Akon Business and Economic Review, 21, 7-19.

22. Deegan, C., \& Rankin, M. (1997). The Materiality of Environmental Information to users of Annual reports. Accounting, Auditing \& Accountability Journal, 10(4), 562-583. https://doi. org/10.1108/09513579710367485

23. Fauzi, H. (2009). Corporate Social and Financial Performance: Empirical Evidence from American Companies. Globsyn Management Journal, Forthcoming. Retrieved from http://ssrn.com/abstract $=1489494$ (accessed on April 25, 2017). 
24. Fernando, G., Wojciech, P., \& Justynia, P. (2016). Corporate Sustainability and Shareholder Wealth. Evidence from British Companies and Lessons from the Crisis. Retrieved from MDPI: www. mdp.com/journal/sustainability.

25. Fiori, G., Di Donato, F., \& Izzo, M. F. (2009). Corporate Social Responsibility and Firms Performance: An Analysis of Italian Listed Companies. Paper presented at the Performance Measurement Association Conference (PMA), April 14, 2017, Dunedin, New Zealand. Retrieved from https://eprints.luiss.it/374/1/ Fiori_2007_03_OPEN.pdf

26. Freeman, R. E. (1984). Strategic Management: A Stakeholder Approach. London: Financial Times Prentice Hall. Retrieved from https://www.amazon. co.uk/Strategic-ManagementStakeholder-Approach-Business/ dp/0273019139

27. Freeman, E. R. (2004). A stakeholder theory of Modern Corporation. U: Beauchamp TL, Bowie NE [ur.] Ethical theory and business.

28. Gerard, H., \& Thierry, P. (2015). The relationship between Corporate Social Responsibilities and Financial Performance; what is the causality? Journal of Business \& Management, 4(1), 1843. https://doi.org/10.12735/jbm. v4i1p18

29. Granger, C. W. J. (1969). Investigating causal relations by econometric models and crossspectral methods. Econometrica, 37(3), 424-438. https://doi. org/10.2307/1912791

30. Griffin, P., \& Sun, Y. (2012). Going Green: Market Reaction to Corporate Social Responsibility. Newswire Releases.

31. Guenster, N., Bauer, R., Derwall, J., \& Koedijk, K. (2011). The Economic Value of Corporate Eco-Efficiency. European Financial Management, 17(4), 679-704. https://doi.org/10.1111/ j.1468-036X.2009.00532.x
32. Hackston, D., \& Milne, J. M. (1996). Some Determinants of Social and Environmental Disclosures in New Zealand companies. Accounting, Auditing and Accountability journal, 9(1), 77-108. Retrieved from https:// www.researchgate.net/...Milne/... Some_Determinants_of_Social_ and_Environ

33. Honghui, C., \& Xiayang, W. (2011). Corporate social responsibility and corporate financial performance in China: an empirical research from Chinese firms. Corporate Governance: The international journal of business in society, 11(4), 361-370. https://doi. org/10.1108/14720701111159217

34. Hassel, L., Nyquist, S., \& Nilsson, H. (2005). The Value Relevance of Environmental Performance. European Accounting Review, 14(1), 41-61. https://doi.org/10.1080/0963818042000279722

35. Hoechle, D. (2007). Robust standard errors for panel regressions with cross-sectional dependence. Stata Journal, 7(3), 281-312. Retrieved from https:// econpapers.repec.org/article/ tsjstataj/v_3a7_3ay_3a2007_3ai_3 a3_3ap_3a281-312.htm

36. Hopkins, M. (2003). The Planetary Bargain - CSR Matters. Earthscan: London. Retrieved from https://www.taylorfrancis. com/books/9781136552663

37. Jacobs, B. W., Singhal, V. R., \& Subramanian, R. (2010). An Empirical Investigation of Environmental performance and the market Value of the firm. Journal of Operations Management, 28(5), 430-441. Retrieved from https://scholars.opb.msu.edu/ en/publications/an-empiricalinvestigation-of-environmentalperformance-and-the-m-2

38. Jacobs, R. L., Leamer, E. E., \& Ward, M. P. (1979). Difficulties with testing for causation. Economic Inquiry, 17(3), 401-413.

39. Kenneth, E. A., Archie, B. C., \& John, D. H. (1985). An Empirical Examination of the Relationship between Corporate Social
Responsibility and Profitability. Academy of Management Journal, 28(2), 446-463. Retrieved from https://www.researchgate.net/.../ Archie.../273122258

40. King, A. A., \& Lenox, M. J. (2001). Does it really pay to be Green? An Empirical Study of Firm Environmental \& Financial Performance. Journal of Industrial Ecology, 5(1), 105-116. Retrieved from www.greeneconomics.net/ DoesItPayToBeGreen.pdf

41. Lankoski, L. (2000). Determinants of environmental Profit: An analysis of the firm - level Relationship between environmental performance and economic performance (Doctoral Dissertation, Helsinki University of Technology). Retrieved from http://lib.tkk.fi/Diss/2000/ isbn9512280574/

42. Makin, R., Francoeur, C., \& Bellavance, F. (2009). Causality between Corporate Social Performance and Financial Performance: Evidence from Canadian Firms. Journal of Business ethics, 89(3), 409-422. https://doi.org/10.1007/s10551008-0007-7

43. Mahoney, L., \& Roberts, R. W. (2007) Corporate Social \& Financial Performance \& Institutional Ownership in Canadian Firms. Accounting Forum, 31, 233-253. Retrieved from https://www.researchgate.net/ publication/228306627_Corporate_Social_and_Environmental_ Performance_and_Their_Relation to_Financial_Performance_and_ Institutional_Ownership_Empirical_Evidence_on_Canadian_Firms

44. Mcwilliams, A., \& Siegel, D. (2001). Corporate Social Responsibility Theory: A Theory of the Firm Perspective. Academy of Management Review, 26(1), 117-127. https://doi.org/10.5465/ amr.2001.4011987

45. Moneva, J. M., \& Ortas, E. (2008). Are Stock Markets Influenced by Sustainability Matter? Evidence from European Companies. International Journal of Sustainability Economy, 1(1). https://doi.org/10.1504/ IJSE.2008.020013 
46. Murray, A., Sinclair, D., Power, D., \& Gray, R. (2006). Do Financial markets care about Social \& environmental disclosure? Further evidence \& exploration from the UK. Accounting, Auditing \& Accountability Journal, 19(2), 225228. Retrieved from https://www. st-andrews.ac.uk/media/csear/ discussion-papers/CSEAR_dpsfinance-dofinmar.pdf

47. Nakao, Y., Nakano, M., Amano, A., Kokubu, K., Matsumura, K., \& Gemba, K. (2007). Corporate Environmental \& Financial Performance and the Effects of Information Based Instruments of Environmental Policy in Japan. International Journal of Environment and Sustainable Development, 6(1), 95-112. Retrieved from https://pdfs. semanticscholar.org/2fa3/e5ba8d$70 \mathrm{f} 18 \mathrm{a} 6 \mathrm{c} 5440 \mathrm{c} 8 \mathrm{~b} 5836 \mathrm{e} 0 \mathrm{db}-$ 6c5bf68.pdf

48. Nnamani, J. N., Onyekwelu, U. L., \& Ugwu, O. K. (2017). Effect of Sustainability Accounting and Reporting on Financial Performance of Firms in Nigeria Brewery Sector. European Journal of Business and Innovation Research, 5(1), 1-15.

49. Oba, V. C., Fodio, M. I., \& Soje, B. (2012). The Value Relevance of Environmental Responsibility, Information Disclosure in Nigeria, Acta Universitatis Danubius. Economica, 8(6), 100-113. Retrieved from http://journals. univ-danubius.ro/index.php/oeconomica/article/view/1534/1353

50. O’Donovan, G. (2002).

Environmental Disclosure in the Annual Report extending the applicability \& predictive cover of legitimacy theory. Accounting, Auditing \& Accountability Journal, 15(3), 344-371. https://doi. org/10.1108/09513570210435870

51. Ohlson, J. A. (1995). Earnings, book values, and dividends in equity valuation' Contemporary Accounting Research, 11(2), 661-687. Retrieved from https:// onlinelibrary.wiley.com/doi/ abs/10.1111/j.1911-3846.1995. tb00461.x

52. Okegbe, T. O., \& Egbunike. F. C. (2016). Corporate Social
Responsibility and Financial Performance of Selected Quoted Companies in Nigeria. Nigerian Journal of Social Development, 5(4). https://doi.org/10.12816/0033096

53. Olubukola, R. U., Uwuigbe, U., Jimoh, J., Ebeguki, E. I., \& Olufemi, A. O. (2016). Value relevance of financial statements and share price: a study of listed banks in Nigeria. Banks and Bank Systems, 11(4), 135-143. http:// dx.doi.org/10.21511/bbs.11(41).2016.04

54. Orlitzky, M. (2013). Corporate Social Responsibility, Noise, and Stock Market Volatility. Academy of Management Perspective, 27(3), 238-254. https://doi.org/10.5465/ amp.2012.0097

55. Orlitzky, M., Schmidt, F. L, \& Rynes, S. L. (2003). Corporate Social and Financial Performance. A Meta-Analysis. Organizational studies, 24(3), 403-441. Retrieved from https://ir.uiowa.edu/tippie_pubs/18/

56. Osariemen, A., Edosa, J. A., Uwuigbe, U. \& Uwuigbe, O. R. (2018). Audit committee attributes and audit quality: a benchmark analysis. Business: Theory and Practice, 19, 37-48. https://doi. org/10.3846/btp.2018.05

57. Ozordi, E., Uwuigbe, U., Obarakpo, T., Ikumapayi, T., \& Gbenedio, A. E. (2018). Corporate diversity and corporate social environmental disclosure of listed manufacturing companies in Nigeria. Problems and Perspectives in Management, 16(3), 229-244. http://dx.doi.org/10.21511/ ppm.16(3).2018.19

58. Pinney, C. (2001). Imagine Speaks Out. How to Manage Corporate Social Responsibility and Reputation in a Global Marketplace: the challenge for Canadian Business. Retrieved from shodhganga.inflibnet.ac.in/jspui/ bitstream/10603/171715/8/08_ chapter\%202.pdf

59. Plumlee, M., Brown, D., Hayes, R., \& Marshall, S. (2010). Voluntary Environmental Disclosure Quality \& Firm Value: Further Evidence. Retrieved from http://daneshyari. com/article/preview/1005809.pdf
60. Priyanjka, A (2013) Relationship between Environmental Responsibility and Financial Performance of firm: A Literature Review. IOSR Journal of Business \& Management, 13(1), 13-22. https://doi. org/10.9790/487X-1311322

61. Solabomi, O. A., \& Uwuigbe, U. (2013). Effects of Corporate Governance on Corporate Social and Environmental Disclosure among listed firms in Nigeria. European Journal of Business and Social Sciences, 2(5). 76-92. Retrieved from http:// eprints.covenantuniversity.edu. ng/1565/\#W4fiKugzaUk

62. Solomon, A. Z., Oyerogba, E., \& Olaleye, M. O. (2014). Effect of Corporate Social Responsibility Performance (CSR) on stock prices: Empirical Study of Listed Manufacturing Companies in Nigeria. Journal of Business Management, 16(8), 112-117. Retrieved from http://iosrjournals. org/iosr-jbm/papers/Vol16-issue8/ Version-2/M01682112117.pdf

63. Sukanya, C. N., \& Yudhvir, S. (2015). The Impact of Corporate Social responsibility on Firms Financial Performance in South Africa. School of Economics \& Business Sciences, 9(2), 193-214. https://doi.org/10.5709/ce.18979254.167

64. Summers, L. H. (1986). Does the stock market rationally reflect fundamental values? The Journal of Finance, 41(3), 591-601.

65. Taiwo, P. F., \& Afolabi, E. O. (2016). Determinants of Share Price on the Nigerian Stock Exchange. International Journal of Business and Applied Social Science, 2(7), 49-60. Retrieved from https://ijbassnet.com/storage/app/publications/579d52144d 55f11469927956.pdf

66. Uwuigbe, U., Agba, L. U., Jimoh, J., Olubukunola, R. U., \& Rehimetu, J. (2017). IFRS adoption and earnings predictability: evidence from listed banks in Nigeria. Banks and Bank Systems, 12(1), 166-174. http://dx.doi. org/10.21511/bbs.12(1-1).2017.10 
67. Van Beurden, P., \& Goessling, T (2008). The worth of values - A literature review on the relation between corporate social and financial performance. Journal of Business Ethics, 82(2), 407-424. https://doi.org/10.1007/s10551-0089894-x

68. Waddock, S. A., \& Graves, S. B. (1997). The corporate social performance - financial performance link. Strategic Management Journal, 18(4), 303-319. Retrieved from https://www.jstor. org/stable/3088143?seq=1\#page_ scan_tab_contents

69. Wang, G. Y. (2011). Corporate Social Responsibility and Stock Performance - Evidence from Taiwan. Scientific Research, 2, 788-799. https://doi.org/10.4236/ me.2011.25087
70. Wan Hussin, W. N., Che-Adam, N., Lode, N. A., \& Kamardin, H. (2005). Determinants of early adoption of FRS 114 (segment reporting) in Malaysia. Asian Academy of Management Journal, 10(2), 1-20. www.un-documents. net 9our common future: Report of the world commission on environmental development documents: Gathering a body of Global Agreements. Retrieved from https://papers.ssrn.com/ sol3/papers.cfm?abstract_ id $=1025329$

71. World Business Council for Sustainable Development (2002). The Business Cases for Sustainable Development. Retrieved from https://link. springer.com/10.1007/978-3642-28036-8_196
72. Yung-Chih (2011). Corporate Social Responsibility \& stock performance - Evidence from Taiwan: Modern Economy Scientific Research, 2011(2), 788-799. https:// doi.org/10.4236/me.2011.25087

73. Zhang, J. (2016). Does Corporate Social Responsibility Affect Financial Performance of Listed Manufacturing firms in Germany? (A Master's Thesis). Retrieved from https://essay.utwente.nl/70938/1/ Zhang_MA_BMS\%20.pdf

74. Zsuzsanna, D., \& Berna, K. (2014). Stock Market Reactions to Environmental News in the Food Industry. Journal of Agricultural and Applied Economics, 46(2), 209-225. Retrieved from https:// ageconsearch.umn.edu/bitstream/169058/2/jaae674.pdf 